\title{
GASTON DELIGNE
}

Por Lourdes Victoria Incháustegui Santoni

\section{SIGLO XX: MARCO HISTORICO}

Al llegar el Siglo XX nuestro país alcanza su madurez intelectual con la formación de dos grandes hombres de letras: Gastón Fernando Deligne, en la poesía y Pedro Henríquer ITreña en el campo de la erudición y de la crítica literaria.

Durante el presente siglo la historia de la literatura nacional podría dividirse en dos grandes períodos: el de la generación anterior al año 1930 y el que surge durante la "Era de Trujillo," considerada por muchos como la de la plenitud intelectual.

SU VIDA.

Gastón Fernando Deligne nace en Santo Domingo el 23 de octubre de 1861, hijo de Gastón Deligne y Angela Figueroa. Hizo sus estudios bajo la dirección del filántropo Francisco Xavier Billini. Colaboró asiduamente en numerosas publicaciones de revistas y periódicos. Murió en San Pedro de Macorís el 18 de enero de 1913 al quitarse la vida después de sufrir al igual que su hermano de la cruel y desgarrante lepra que lo despedazaba en plena vida. 
Gastón Fernando Deligne surge como vínculo entre la tradición neoclásica y romántica y las corrientes del siglo XX. Lo situamos en la época post-romántica y es considerado realista y racionalista. Esta modalidad muy en boga en los años 1880 era respaldada por muchos como, entre otros, Eugenio María de Hostos, quien implantó la enseñanza racionalista.

Con Deligne aparece la poesía sicológica y la poesía política que es de agudo sentido crítico. Introduce el tiempo y el retrospectivismo.

$\mathrm{Su}$ obra constituye un fehaciente giro del lenguaje poético. Enriqueció la poesía dominicana con una sensibilidad diferente y con gran originalidad, no sólo en el extenso caudal de expresiones e imágenes, sino en el contenido filosófico y la dignidad conceptual de que revistió sus composiciones. Es considerado el príncipe de los líricos nacionales.

$\mathrm{Su}$ alta meditación poética recoge las cosas más comunes y les infunde fuerza, alejándolas de toda vulgaridad y repetición.

Poseyó un sinnúmero de recursos técnicos tales como- poder de condensación, dominio de contrastes, variedad de recursos verbales, dicción, imaginación plástica. Estos detalles le permiten expresar las ideas más prosáicas y realistas junto con las más altas y elevadas.

Como escritor realista, aspira a captar en su obra la vida tal y como es; quiere suprimir el yo de todo lo que escribe. Se concentra en la razón, pensamiento, sustancia, rigor, mesura. El realismo es una reacción contra el subjetivismo romántico. Entre sus características se cuentan: ambiente local, descripción de costumbres y sucesos contempora- 
neos, afición al detalle, espíritu de imitación fotográfica, reproducción del lenguaje coloquial o familiar de giros regionales.

Deligne como realista quiere hacer poesía con rigor científico (positivismo francés), confundiendo que la ciencia procede por acumulación y sucesión de experiencias y que el poeta es siempre un universo en sí, el cual descubre el mundo desde la expresión personal que es su verso.

Dice en una ocasión sobre su ejercicio poético:

"Siendo el arte, pues, genuino producto de la observación, por cuanto reside menos en las cosas que en la mente donde se vivifican; (...;) la impresión directa individual, que impulsa a decir lo que se ve, como se ve, lo que se siente, cómo se siente, y lo que se piensa, cómo se piensa, es la base y el punto inicial de toda labor de belleza literaria, buena, sana y viable."

\section{INFLUENCIA DE OTROS POETAS.}

El eco se hace presente en la elegía a la memoria del Padre Billini.

El romanticismo se manifiesta en Deligne por vía del sentimentalismo con que en general rodea sus cuadros pretendidamente realistas. En ellos hay una insistencia en el horror, como si la desgracia y la muerte estuvieran a la puerta de la vida constantemente.

En "Del Patíbulo": "el sitio horrendo del horrendo trance."

La más marcada influencia es la de Campoamor, pero Deligne llega a superarlo. Campoamor aseguraba que "escribir poesía era convertir las ideas en imágenes". Esta actitud de ambos poetas se debe al contacto que tuvieron con la poesía francesa de 
carácter positivista. (La filosofía positivista sólo acepta el método experimental).

Entre los elementos de esa-influencia están la frecuente repetición, sobre todo al final de las estrofas, de un mismo vocablo en uno o dos versos de carácter epifonémico (exclamación al final del verso). El propósito de esto es mantener la impresión del lenguaje simple y acentuar la eficacia expresiva mediante el uso de los mismos términos en oraciones diferentes.

Ejemplo en "Angustias":

"que siempre que el carácter se despierta

el caracter despierta en los pesares"

"le premia con un beso, si es que rie, le acalla, si es que llora, con un beso".

Otras peculiaridades expresivas del estilo de Campoamor podrían señalarse, como el uso repetido de locuciones subjuntivas y la onomástica (ciencia que trata sobre los propios nombres) de sus poemas dramáticos de la primera época como, es el empleo del vocabulario que no evita la frase prosaica o vulgar.

Ejemplo de "Aniquilamiento":

"Amor, gloria, riquezas, por ventura no pueden ser a su disfrute análogo"

"al rubio y cotidiano pan de trigo que no indigesta nunca ni empalaga".

Deligne tuvo una actitud ética que contrasta con el desenfado y el regocijo de Rubén Darío. En Oneiros dice:

"iqué os queda, si el mal ahuyenta la luz del mundo moral i". 
En ocasiones se reviste de pinceladas parnasianas (modernismo) para alcanzar la plasticidad: En "De Luto" tenemos:

"Del traje negro y de su negro broche surgen las líneas de tu faz marmóreas".

En el poema Aniquilamiento parece estar influenciado por los "Poemas Hindúes" del libro de Leconte de Lisle (influencias orientales)o parnasianas).

A través de su obra observamos el proceso que como poeta sigue: "Confidencias de Cristina", recoge los últimos síntomas románticos. Con "Aniquilamiento" inicia definitivamente un proceso de racionalización e intelectualización progresiva en busca de la eficiencia conceptual y reflexiva. Deligne se opone al modernismo demostrando desconocimiento del carácter dinámico del arte.

La poesía de Deligne cierra el primer ciclo de la poesía dominicana. Su obra, como toda obra de transición, es un muestrario de la herencia clásica y de preocupaciones nuevas, propias de este siglo.

CLASIFICACIONDE SU OBRA.

La obra de Gastón Deligne podría clasificarse en:

a. Poesía política: Ololoi"

b. Poema de carácter filosófico: "Aniquilamiento".

c. Poema sicológico: "Angustia".

d. Poema descriptivo: "En el Botado". 
Es la manifestación característica de la lírica hispanoamericana.

Deligne dejó un poema que es un documento sobre la dictadura de Ulises Heureaux, escrito con el énfasis de un testigo implacable. En "Ololoi" alcanza Deligne su más acabada muestra de poesía política.

Está elaborado de forma que los efectos dramáticos son dosificados con destreza tal, que el crescendo llega al climax en el preciso momento del ajusticiamiento del Dictador. Más que una condenación de tipo político, el poema es una cogitación (reflexión-meditación) moral sobre los males de las dictaduras.

Ya en la primera estrofa podemos observar el extraordinario poder de condensación en Deligne:

“Tú, prudencia, que hablas muy quedo y te abstienes, zebrada de miedo: tú, pereza, que el alma te dejas

en un plato de chatas lentejas: tú, apatía, rendida en tu empeño por el mal africano del sueño; y ¡oh tú, laxo, no importa que aspiras sin vigor, y mirando nó miras!....

\section{EL POEMA DE AMBIENTE SICOLOGICO.}

Es aquí donde se destaca la originalidad de Deligne. Entre los poemas de esta modalidad se cuenta "Angustias" y "Confidencias de Cristina". No sólo recogen el cuadro sicológico sino también proyecciones de la sensibilidad humana. En estos 
poemas el autor desarrolla un pequeño drama sin acción donde se plantea una crisis del sentimiento, y las fases evolutivas de éste.

"Angustias" está escrito en 1886 por eso es importante, como documento social, ya que allí se plantea el problema de la mujer pobre dominicana que es madre soltera.

En "Confidencias de Cristina" encontramos ya en los primeros versos, la situación espiritual de una colegiala. Luego se van atravesando etapas, la segunda, cuando la joven se convierte en doncella, creyéndose digna de atención e insensible a la desgracia humana. Deligne se vale de un recurso, un huracán tropical, para poner de relieve los sentimientos del padre de la doncella:

"cuando entre intermitencias de lluvias, se oía el crujir de las deshechas ramas o el desastre de un árbol, mi buen padre ¡Ay de los cosecheros!, murmuraba.

Cuando además el huracán traía ecos del bravo mar convulso en rabia contra el peñasco rígido, decía; "Protege al que navega, Virgen Santa". Salmodia que llegaba a mis oídos con rumor sin alcance ni sustancia: muy venturosa estaba entre mí misma para pensar ¡no importa en qué desgracia!.”

En "Angustias" introduce la secuencia temporal y el retrospectivismo:

"Su mano de mujer está grabada hasta el lazo azul de la cortina no hay jarrones de China pero es toda la estancia una monada." 
Es importante resaltar la capacidad de Deligne para pasar de un plano a otro y ofrecer contrastes violentos de la vida de Angustias.

EL POEMA DE CARACTER FILOSOFICO.

Del poema "Aniquilamiento":

“¡Ah! Que con el poder formó en su séquito la innoble adulación parasitaria, y con frecuencia se encontró en su vía

a la negra ojeriza atravesada, y le enlodó en su carro la calumnia y la injusticia visitó su casa...".

\section{EL POEMA DESCRIPTIVO}

Deligne incursiona en diversos ámbitos temáticos tales como la historia, la filosofía, el paisaje dominicano. A esto se le ha denominado "poesía descriptiva."

Reproduce la flora y la fauna nativas con el propúsito de definir lo dominicano.

De "En el Botado":

"Su flameante armazón de tabla oscura, su gris penacho de lucientes yaguas hacían reveberar con nuevas aguas la circundante joya de verdura."

El paisaje era un instrumento devorador:

"Un bejucal de plantas trepadoras, que en torno a la vivienda cerraban toda senda; avanzando traidoras e indicando a la ruina cuchicheaban: ni se defiende, ni hay quien la defienda." 
Deligne escribió romance que nos permiten formarnos una idea de su concepción de lo dominicano, como en el titulado " $L$ a intervención" donde contiene bastantes juicios antihaitianos.

Concibe la dominicanidad como sinónimo de antihaitianismo.

Es de notar en esta muestra cómo exhibe su dominio del movimiento y de los matices sutiles.

VERSIFICACION.

Renovó el vocabulario con voces peregrinas (extrañas como tumular, paladismo, juncial decalonida, etc.) Empleó formas arcaicas. Intercala, por primera vez, el sustantivo entre los dos calificativos del nombre (dando esto una versificación rebuscada).

Abundan las construcciones hiperbáticas. En "Subjetiva":

“ ¡Así.es mejor!. Vivir en el deseo

en una llama alimentar perpetua;

es vivir abrasados, cual vivían

los mártires, los místicos y ascetas"

En "Ololoi":

"Tras el golpe clamaba y el ay: sea propicia ¡Ololoi! ¡Ololai!."

\section{FORMAS.}

Las elípticas muy en consonancia con su tendencia a la condensación y a la síntesis: Usa giros y modos anticuados. Se ven algunos arcaismos de dicción como en "Confidencias de Cristina": 
"Después, mucho después, volví a alcanzarle entre una nube de criaturas bellas

- estrofas de su hogar-y nunca vide dicha mayor entre mayor miseria".

Su afición al rebuscamiento lo inducen a utilizar expresiones afectadas.

Copia de Cervantes una expresión. Usó también como Rosard, palabras combinadas.

"A la memoria del Padre Billini", $¿$ Quien turba la paz santa de ese Sepulcro - día?. 